\title{
Protection of islet allografts transplanted together with Fas ligand expressing testicular allografts
}

\author{
Y. Takeda ${ }^{1}$, M. Gotoh ${ }^{2}$, K. Dono ${ }^{1}$, M. Nishihara ${ }^{1}$, T. Grochowiecki ${ }^{1}$, F. Kimura ${ }^{2}$, T. Yoshida ${ }^{1}$, Y. Ohta ${ }^{1}$, \\ H. Ota ${ }^{1}$, H. Ohzato ${ }^{1}$, K. Umeshita ${ }^{1}$, T. Takeda ${ }^{1}$, N. Matsuura $^{1}$, M. Sakon ${ }^{1}$, N. Kayagaki ${ }^{3}$, H. Yagita ${ }^{3}$ K. Okumura $^{3}$, \\ M. Miyasaka ${ }^{2}$, M. Monden ${ }^{1}$ \\ ${ }^{1}$ Department of Surgery II, Osaka University Medical School, Osaka, Japan \\ ${ }^{2}$ Department of Bioregulation, Biomedical Research Center, Osaka University Medical School, Osaka, Japan \\ ${ }^{3}$ Department of Immunology, Juntendo University School of Medicine, Tokyo, Japan
}

\begin{abstract}
Summary Fas ligand (FasL) is highly expressed in testicular tissues and thought to be responsible for protection from allograft rejection by inducing apoptosis of anti-graft activated T cells. FasL-expressing islets have been shown to induce a granulocyte-mediated inflammatory reaction. We investigated whether a graft can be protected from alloimmune responses by manipulating the Fas/FasL-system. We transplanted allogeneic islets under the kidney capsule of streptozotocin-induced diabetic mice together with testicular tissue. Significant prolongation of survival of $\mathrm{C} 3 \mathrm{H}$ islet allograft was observed in C57BL/6 (B6) recipients transplanted with $\mathrm{C} 3 \mathrm{H}$ testicular tissue, but not in those transplanted with $\mathrm{C} 3 \mathrm{H}-$ gld testicular tissue expressing non-functional FasL. No significant prolongation was observed in B6-lpr recipients expressing non-functional Fas. Immunohistochemical staining of $\mathrm{C} 3 \mathrm{H}$ testicular tissue in the composite
\end{abstract}

graft showed a high expression of FasL, but not that of the $\mathrm{C} 3 \mathrm{H}$-gld testicular tissue. In situ terminal deoxynucleotidyl transferase-mediated dUDP-biotin catalysed DNA nick-end labelling (TUNEL) staining of a composite graft of $\mathrm{C} 3 \mathrm{H}$ islet and testicular tissue in $\mathrm{B} 6$ recipients demonstrated extensive apoptosis of infiltrating mononuclear cells around the graft. The protective effect of $\mathrm{C} 3 \mathrm{H}$ testicular tissue was abrogated when anti-FasL monoclonal antibody was administered i.p. postoperatively. Our results suggest that FasL-positive testicular allografts protect composite islet allografts and indicate that manipulation of Fas/ FasL mediated apoptosis is a suitable strategy for controlling rejection of islet allografts. [Diabetologia (1998) 41: 315-321]

Keywords Fas, Fas ligand, islet transplantation, testicular tissue, apoptosis, composite graft.
Fas (APO-1, CD95) was originally described as a cellsurface molecule involved in mediating apoptotic cell death of transformed cells [1,2]. In addition, chronically activated human $\mathrm{T}$ cells (e.g. T-cell clones) are also susceptible to Fas-mediated apoptosis [3]. The

Received: 12 September 1997 and in revised form: 14 November 1997

Corresponding author: Dr. M. Gotoh, Department of Bioregulation, Biomedical Research Center, Osaka University Medical School, Suita, Osaka 565, Japan.

Abbreviations: FasL, Fas ligand; TUNEL, in situ terminal deoxynucleotidyl transferase-mediated dUDP-biotin catalysed DNA nick-end labelling; mAb, monoclonal antibody; MST, mean survival time; PBS, phosphate buffered saline; Il, interleukin recent demonstration that lymphoproliferative diseases in $l p r$ and gld mice are caused by defects in the genes encoding Fas and Fas ligand (FasL), respectively [4-6], indicates an important role for these proteins in regulating normal immune responses and maintaining self-tolerance. Recent findings also suggest a role for FasL in preventing allogeneic rejection of testis grafts and in establishing immune privileged status of anterior chamber of the eye [7, 8]. Moreover, Lau et al. [9] demonstrated that islet allograft rejection could be prevented using engineered syngeneic myoblasts expressing FasL which were transplanted together with allogeneic islets in mice. In contrast, Allison et al. [10] recently reported that FasL-expressing islets were not protected from allograft rejection, and Kang et al. [11] also reported that islets infected with adenoviral vector containing 
the murine FasL cDNA underwent accelerated neutrophilic rejection.

The above studies indicate that the role of FasL in regulation of allograft rejection is still uncertain. In the present study, we show that islet allograft transplanted together with FasL-expressing testicular allografts can be protected in a Fas/FasL-dependent fashion.

\section{Materials and methods}

Animals. Male C3H/HeJ (C3H) and C57BL/6J (B6) mice were purchased at 7 weeks of age from CLEA Japan, Inc. (Tokyo, Japan). C3H/HeJ-gld/gld (C3H-gld) and C57BL/6J-lpr/lpr (B6-lpr) mice were purchased at 5-7 weeks of age from Japan SLC, Inc. (Hamamatsu, Japan). ICR $n u / n u$ mice were obtained from Charles River Japan, Inc. (Kanagawa, Japan). Mice were reared in a specific pathogen-free environment at the Institute of Experimental Animal Sciences, Osaka University Medical School (Osaka, Japan).

Monoclonal antibodies. Anti-mouse FasL monoclonal antibody (mAb) (K10) [12] was obtained by injecting a hybridoma into nude mice and the collected ascitic fluid was purified with $50 \%$ saturated ammonium sulphate (SAS) precipitation and protein G-Sepharose (MAbTrapTMGII; Pharmacia Biotech, Uppsala, Sweden). Biotinylation of K10 was carried out with N-hydroxysuccinimido-biotin (H-1759, Sigma Chemicals Co., St Louis, Mo., USA). The K10 mAb dose not react with non-functional FasL expressed in $\mathrm{C} 3 \mathrm{H}$ gld mice [12]. Mouse anti-rat CD54 mAb (1A29) [13] which does not crossreact with mouse CD54, was used as a control $\mathrm{mAb}$.

Testicular tissue transplantation. $\mathrm{C} 3 \mathrm{H}$ and $\mathrm{C} 3 \mathrm{H}$-gld mice were used as testis donors. B6 and B6-lpr mice were used as recipients. A pellet $(20 \mu \mathrm{l})$ of testicular tissue, which was prepared by passage through an 18 gauge needle after removal of the capsule, was transplanted under the kidney capsule. The grafted testicular tissue was subjected to histological analysis up to 10 weeks post-transplantation.

Islet and testicular tissue transplantation. $\mathrm{C} 3 \mathrm{H}$ and $\mathrm{C} 3 \mathrm{H}-$ gld mice were used as testis and islet donors. B6 and B6-lpr mice were used as recipients. Islets were isolated by stationary collagenase digestion as described previously [14]. The number of Sertoli cells in each testicular tissue preparation was counted under light microscopy based on the description of Fawcett et al. [15]. A composite graft of $\mathrm{C} 3 \mathrm{H}$ islets (300-400 islets $=2 \mu \mathrm{l}$ ) with $\mathrm{C} 3 \mathrm{H}$ or $\mathrm{C} 3 \mathrm{H}$-gld testicular tissue (containing $4.0 \pm 0.2 \times 10^{5}$ Sertoli cells $=2 \mu \mathrm{l}$ ) was transplanted under the kidney capsule of streptozotocin-induced diabetic B6 or B6lpr mice. We also examined the effect of reducing or increasing $\mathrm{C} 3 \mathrm{H}$ testicular tissue $(1 \mu \mathrm{l}$ or $10 \mu \mathrm{l})$ on islet allograft survival in B6 mice. Rejection was defined by a blood glucose level of more than $16.7 \mathrm{mmol} / \mathrm{l}$.

In the next series of transplantations, a number of the recipients with a composite graft of $\mathrm{C} 3 \mathrm{H}$ islets and testicular tissue were injected with anti-mouse FasL mAb (K10) or control mAb (1A29) (0.1 mg i.p. on days 2, 4, 6). Finally, C3H islets and $\mathrm{C} 3 \mathrm{H}$ testicular tissue were transplanted separately in another group of B6 recipients into the contralateral renal subcapsular space.
Immunohistological analysis. The grafts were harvested from recipients by nephrectomy 8 days after the transplantation. The tissues were fixed in $4 \%$ paraformaldehyde for $12 \mathrm{~h}$. Paraffin-embedded sections were stained with haematoxylin and eosin and evaluated by light microscopy. For detection of FasL in the graft, the tissue sections were rinsed in phosphate buffered saline (PBS) and endogenous peroxidase activity was blocked with $1.0 \% \mathrm{H}_{2} \mathrm{O}_{2}$ and $0.1 \% \mathrm{NaN}_{3}$ for $20 \mathrm{~min}$ at room temperature. Next, the sections were rinsed three times for $5 \mathrm{~min}$ in PBS, and biotinylated $\mathrm{mAb}$ to FasL (K10) was added to the sections at $150 \mu \mathrm{g} / \mathrm{ml}$ for $2 \mathrm{~h}$ at room temperature. The slides were washed three times for 5 min with PBS and antibody binding was visualized using a peroxidase-labelled biotin-avidin detection systems (Histofine SAB-PO kit; Nichirei Co., Tokyo, Japan) with diaminobenzidine as the substrate.

For detection of Fas in the graft, the tissue sections were incubated with $10 \mu \mathrm{g} / \mathrm{ml}$ of rat anti-mouse Fas mAb (RMF-6 D027-3; Medical and Biological Laboratories Co., Nagoya, Ja$\mathrm{pan}$ ) in a humidified chamber for $2 \mathrm{~h}$ at room temperature. The sections were washed three times for $5 \mathrm{~min}$ in PBS, followed by the addition of fluorescein isothiocyanate (FITC)-conjugated goat anti-rat immunoglobulin $(\mathrm{IgM}+\mathrm{IgG}, \mathrm{H}+\mathrm{L}$, Southern Biotechnology Associates, Inc., Birmingham, Ala., USA). After washing three times for $5 \mathrm{~min}$ in PBS, antibody localization was determined using a fluorescence microscope.

Detection of apoptosis. Apoptotic cells in paraffin-embedded sections were stained by the terminal deoxynucleotidyl transferase (TdT)-mediated dUDP-biotin catalysed DNA nick-end labelling (TUNEL) method using Apop Tag kit (Oncor S7100, Gaithersburg, Md., USA) with diaminobenzidine as the substrate.

Statistical analysis. Each group consisted of five or more mice. All experiments were repeated three or four times, and representative data are shown in the Figures. Transplant survival time in different experimental groups was compared using the Breslow-Gehan-Wilcoxon test. Student's $t$-test was used for comparison of paired and non-paired measurements. $P$-values lower than 0.05 were considered to be significant. All statistical calculations were performed using StatView-J 4.11 for Macintosh system 7.5 software.

\section{Results}

Testicular allograft survival under the kidney capsule of $\mathrm{B} 6$ mice. $\mathrm{C} 3 \mathrm{H}$ testicular tissue was histologically identified in B6 recipients up to 3 weeks after transplantation with relatively little cell infiltration. In contrast, no $\mathrm{C} 3 \mathrm{H}$-gld testicular tissue was detected in $\mathrm{B} 6$ recipients and only massive cell infiltration was noted. $\mathrm{C} 3 \mathrm{H}$ testicular tissue was also histologically destroyed in B6-lpr mice (data not shown). These findings suggest that protection of testicular allografts is possible only when both graft FasL and recipient Fas are functional.

Composite graft survival under the kidney capsule of B6 mice. B6 islet alone or B6 islet and testicular tissue composite grafts survived over the period of observation (10 weeks) when transplanted under the kidney 


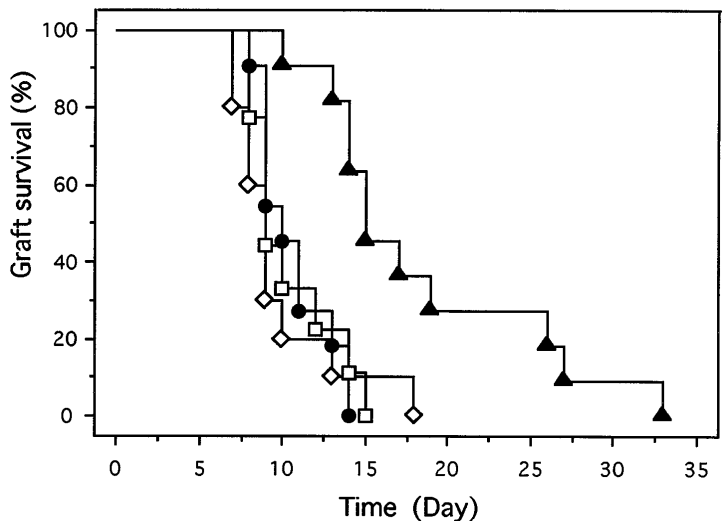

Fig. 1. Survival of islet and testicular composite graft under the kidney capsule. Protection of islet allografts transplanted together with Fas ligand expressing testicular allografts.

$\mathrm{C} 3 \mathrm{H}$ islets $(\mathrm{O})$ were transplanted under the kidney capsule of streptozotocin-induced diabetic B6 mice. A composite graft of $\mathrm{C} 3 \mathrm{H}$ islets with $\mathrm{C} 3 \mathrm{H}(\boldsymbol{\Delta})$ or $\mathrm{C} 3 \mathrm{H}$-gld $(\square)$ testicular tissue was transplanted under the kidney capsule of diabetic B6 or B6-lpr $(\diamond)$ mice. Significant prolongation of $\mathrm{C} 3 \mathrm{H}$ islet allograft survival was observed in B6 mice transplanted with $\mathrm{C} 3 \mathrm{H}$ testicular tissue, but not in the mice transplanted with $\mathrm{C} 3 \mathrm{H}-$ gld testicular tissue. No significant prolongation was observed in B6-lpr mice

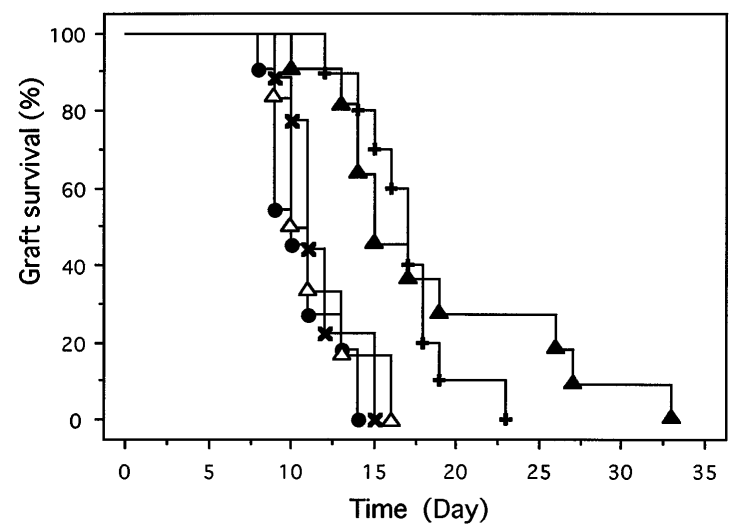

Fig. 2. Abrogation of protection by testicular tissue following anti-FasL mAb treatment or contralateral grafting.

Mice transplanted with $\mathrm{C} 3 \mathrm{H}$ islet alone (O) or testicular composite graft $(\boldsymbol{\Delta})$ were injected with $0.1 \mathrm{mg}$ i.p. of anti-FasL (X) or control mAb (+) on days 2, 4, 6. The protective effect of testicular tissue was abrogated by administration of antiFasL mAb. $\mathrm{C} 3 \mathrm{H}$ islets and $\mathrm{C} 3 \mathrm{H}$ testicular tissue were transplanted separately into the contralateral renal subcapsular space of B6 recipients $(\triangle)$. The protective effect of FasL-positive testicular tissue is site specific

capsule of syngeneic animals. All $\mathrm{C} 3 \mathrm{H}$ islet allografts were rejected by day 14 with a mean survival time (MST) of $10.6 \pm 2.2$ days, whereas $\mathrm{C} 3 \mathrm{H}$ islet and testicular tissue (approximately $4 \times 10^{5}$ Sertoli cells) composite allografts survived significantly longer with an MST of $17.5 \pm 9.1$ days ( $p<0.01$ vs control) (Fig. 1). $\mathrm{C} 3 \mathrm{H}$ islet and $\mathrm{C} 3 \mathrm{H}$-gld testicular composites were rejected in a manner similar to that of the con- trol with an MST of $10.4 \pm 2.6$ days. When $\mathrm{C} 3 \mathrm{H}$ testicular and islet composite grafts were implanted in B6lpr mice, they were rejected with an MST of $9.8 \pm 3.4$ days. Thus, the protective effect was observed only in the presence of functional FasL in testicular tissue and functional Fas in the recipient.

Transplantation of only $50 \%$ of the mass of $\mathrm{C} 3 \mathrm{H}$ testicular tissue $\left(2 \times 10^{5}\right.$ Sertoli cells $)$, together with $\mathrm{C} 3 \mathrm{H}$ islet, did not prolong graft survival (MST: $10.3 \pm 2.6$ days). Similarly, when a larger mass of testicular tissue $\left(2 \times 10^{6}\right.$ Sertoli cells $)$ was transplanted, the recipient mice failed to achieve normoglycaemia after transplantation.

Abrogation of allograft survival prolongation by antiFasL $m A b$. When anti-mouse FasL mAb (K10) was administered i.p. postoperatively daily for 3 days (days 2, 4, 6) to B6 recipient mice grafted with a $\mathrm{C} 3 \mathrm{H}$ islet and testicular composite grafts, no significant prolongation was observed and graft survival time was similar to that in untreated mice (11.8 \pm 2.0 days) (Fig. 2). On the other hand, when control mAb (1A29) was administered, significant prolongation was observed (16.9 \pm days, $p<0.01$ vs control). These results further indicated that the protective effect was mediated by FasL.

Survival of islet allografts transplanted separately from testicular allografts. When $\mathrm{C} 3 \mathrm{H}$ testicular tissue was transplanted separately into the contralateral kidney of $\mathrm{B} 6$ mice, the $\mathrm{C} 3 \mathrm{H}$ islet allografts were rejected in a normal manner (12.5 \pm 4.2 days) (Fig. 2$)$. This indicated that the protective effect of testicular tissue was local.

Immunohistological examination of the composite graft. Histological examination of the grafts in each group showed marked mononuclear cell dominant infiltration around the islet tissue, although islet destruction varied among the groups. $\mathrm{C} 3 \mathrm{H}$ islets were still visible and spared from destruction when they were transplanted together with $\mathrm{C} 3 \mathrm{H}$ testicular tissue in $\mathrm{B} 6$ recipient mice (Fig. 3B), whereas their destruction was almost complete when they were transplanted alone (Fig.3A), with $\mathrm{C} 3 \mathrm{H}$-gld testicular tissue (Fig.3C) or when the composite grafts had been transplanted into the B6-lpr mice (Fig. 3D).

The $\mathrm{C} 3 \mathrm{H}$ testicular tissue in the composite graft was positive for FasL expression (Fig. 3F, H), whereas the $\mathrm{C} 3 \mathrm{H}-g l d$ testicular tissue was FasL-negative (Fig. 3G). C3H islets in the composite graft were also negative for Fas expression (Fig. 3J). The infiltrating mononuclear cells around the $\mathrm{C} 3 \mathrm{H}$ islet and testicular tissue showed Fas expression (Fig. 3J) and extensive apoptosis, detected by TUNEL staining (Fig. 3L). However, the infiltrating mononuclear cells in other composite grafts showed minimal evidence of apoptosis (Fig. 3M, N). 

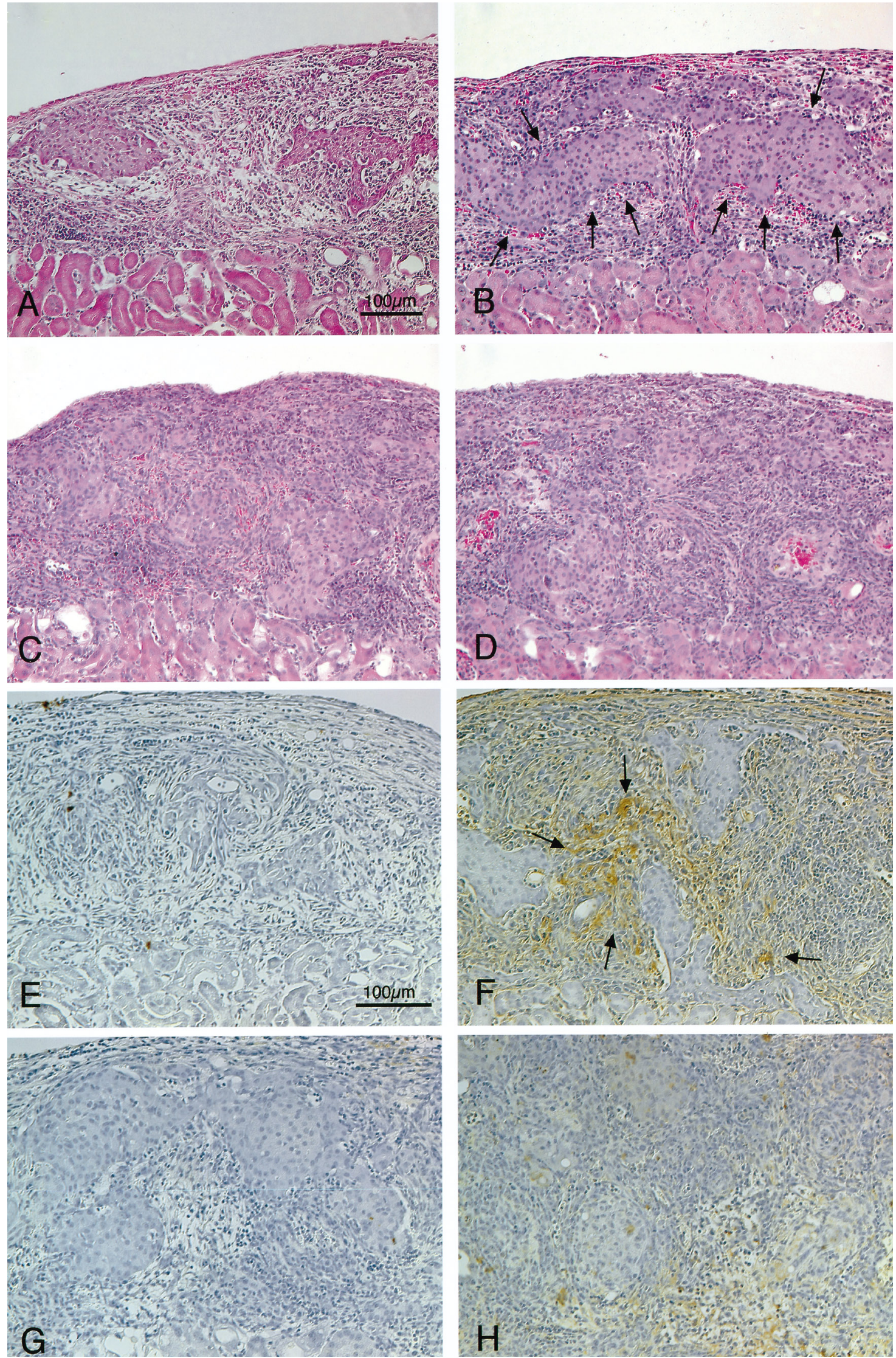

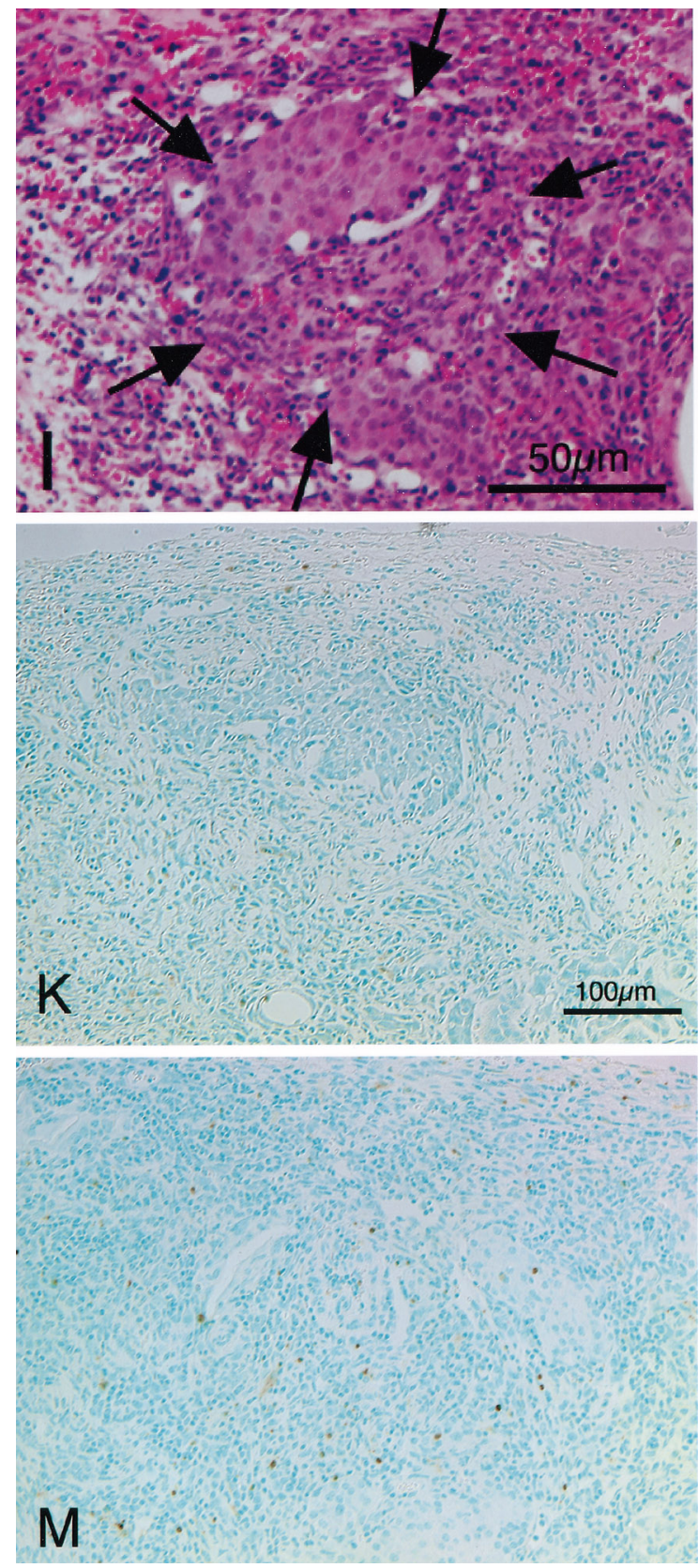

Fig. 3A-N. Histological comparison of $\mathrm{C} 3 \mathrm{H}$ islets and $\mathrm{C} 3 \mathrm{H}$ or $\mathrm{C} 3 \mathrm{H}$-gld testicular tissue composite allograft under the kidney capsule of streptozotocin-induced diabetic B6 or B6-lpr mice.

The graft was dissected 8 days after transplantation, and paraffin sections were stained with haematoxylin and eosin $(\mathbf{A}, \mathbf{B}, \mathbf{C}, \mathbf{D}$, I), or by immunohistochemistry with anti-FasL $(\mathbf{E}, \mathbf{F}, \mathbf{G}, \mathbf{H})$ or anti-Fas (J) mAb. Apoptosis was detected by the TUNEL method $(\mathbf{K}, \mathbf{L}, \mathbf{M}, \mathbf{N})$. A, E, K; Photomicrograph of $\mathrm{C} 3 \mathrm{H}$ islets transplanted under the kidney capsule of B6 mice. B, C, D, F, G, H, I, $\mathbf{J}, \mathbf{L}, \mathbf{M}, \mathbf{N}$; Composite graft of $\mathrm{C} 3 \mathrm{H}$ islets with $\mathrm{C} 3 \mathrm{H}(\mathbf{B}, \mathbf{F}, \mathbf{I}, \mathbf{J}$, $\mathbf{L})$ or $\mathrm{C} 3 \mathrm{H}$-gld $(\mathbf{C}, \mathbf{G}, \mathbf{M})$ testicular tissue was transplanted under the kidney capsule of diabetic B6 or B6-lpr $(\mathbf{D}, \mathbf{H}, \mathbf{N})$ mice. Islets were spared when they were transplanted together with $\mathrm{C} 3 \mathrm{H}$ testicular tissue in $\mathrm{B} 6$ mice (B arrow). $\mathrm{C} 3 \mathrm{H}$ testicular tissue was positive for FasL expression (F, H), whereas that of $\mathrm{C} 3 \mathrm{H}$-gld was FasL-negative (G). Islet tissue (arrow) was negative for Fas expression. Apoptosis of mononuclear cells was noted only when testicular tissue expressing functional FasL was grafted into Fasintact recipient $(\mathbf{L})$
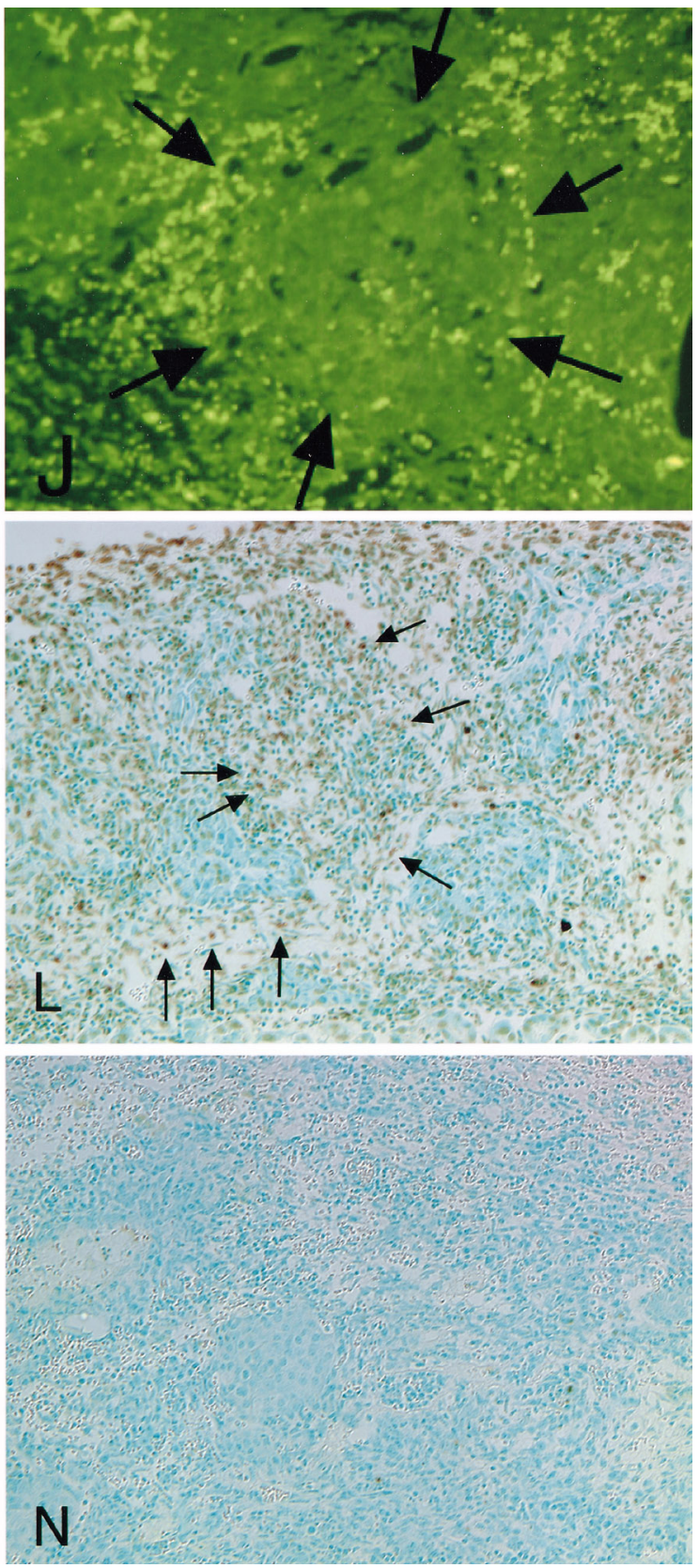

\section{Discussion}

Korbutt et al. [16] have recently shown that cultured testicular cells and islets composite graft can be protected in a rat allogeneic model, although the precise mechanisms were not clearly elucidated. In this study, we demonstrated that prolongation of survival of the composite graft was mediated by Fas-FasL system, which resulted in apoptosis of infiltrating mononuclear cells. Significant prolongation of survival of $\mathrm{C} 3 \mathrm{H}$ composite islet allograft over the control (islet allograft alone) was observed when the testicular tissue was derived from mice with functional FasL and the recipient mice had intact Fas, but not when the testicular tissue was from mice with non-functional FasL or the recipient mice had a defective Fas. The protective 
effect of testicular tissue on islet allograft was abrogated by anti-FasL mAb treatment, but not by control $\mathrm{mAb}$ treatment. These results clearly indicated that FasL expression $\mathrm{C} 3 \mathrm{H}$ testicular tissue could protect $\mathrm{C} 3 \mathrm{H}$ islet allografts.

Our immunohistological studies provided a further confirmation of our hypothesis. $\mathrm{C} 3 \mathrm{H}$ testicular tissue was highly positive for FasL expression, whereas that of $\mathrm{C} 3 \mathrm{H}$-gld was negative. Furthermore, the infiltrating mononuclear cells in the B6 recipients were positive for Fas expression. Extensive apoptosis of mononuclear cells was noted only when testicular tissue expressing functional FasL was grafted together with islets in the recipients having intact Fas. Islet tissue was negative for Fas expression. Therefore, it seems likely that the provision of FasL by testicular tissue can deliver a death signal to infiltrating allo-activated T cells that express Fas.

The use of FasL to protect islet grafts has not always had positive consequences. We have previously shown that subcutaneous engraftment of FasL-transfectants resulted in FasL-mediated recruitment of neutrophils, which in turn led to acute graft rejection [17, 18]. Allison et al. [10] reported that fetal pancreas obtained from transgenic mice expressing mouse FasL on their islet beta cells, were massively infiltrated with neutrophils, but not with lymphocytes. Kang et al. [11] demonstrated that islets infected with adenoviral vector containing FasL cDNA underwent accelerated neutrophilic rejection, and failed to protect the grafts when transplanted into allogeneic hosts. We also examined the infiltrating cells around the testicular tissue under the kidney capsule and found that mononuclear cells were dominant and granulocytes were marginally visible around the testicular allografts in the renal subcapsular space. This finding is compatible with Lau et al. [9] who reported that the infiltrating cells around the graft were mononuclear cells and that extensive apoptosis was evident in these cells, resulting in the protection of composite islet allografts.

The mechanisms for neutrophil recruitment by FasL needs to be determined. Allison et al. [10] reported that most islets of transgenic mice expressing murine FasL on high level were infiltrated by large numbers of neutrophils, eosinophils, and macrophages, whereas islets of transgenic mice with lower levels of FasL had a milder pathology. These results suggest a dose-dependent relationship between FasL expression and intensity of neutrophilic infiltration. Overexpression of FasL may recruit neutrophilic infiltration, and FasL-mediated protection can only occur when a critical amount of FasL is expressed on the graft. It is possible that the expression of FasL leads to upregulation of interleukin (IL)-8 expression in surrounding tissues, which in turn results in the recruitment of neutrophils $[19,20]$, as ligation of Fas on epithelial cells can induce secretion of IL-8 [21, 22]. It is also possible that soluble FasL, which is released from the cell sur- face by metalloprotease cleavage of membranebound FasL [23-25], can act directly as a neutrophil chemotactic factor. In our model in which testicular tissue was used as a physiological source of FasL, no significant IL-8 production in response to appropriate levels of FasL, or no expression of FasL-processing metalloprotease in the testis may be one of the reasons for the successful Fas/FasL-mediated graft protection. Alternatively, some factor derived from the testicular tissue such as transforming growth factor-beta (TGF$\beta$ ) may suppress the FasL-mediated neutrophil recruitment.

Islet expression of Fas, either constitutively or through upregulation by local immune response, is also a critical factor for protection of islets by FasL. Yamada et al. [26] reported that mouse Il-1 alpha induced the expression of Fas on primary cultured mouse islet cells and these islet cells were destructed by an agonistic anti-Fas monoclonal antibody. Chervonsky et al. [27] established transgenic non-obese diabetic mice that expressed FasL on islet cells and found an accelerated onset of diabetes in some transgenic mice. They demonstrated that islet destruction was related to the induction of Fas expression on islet cells. In our model, expression of Fas was not detected on the islet cells while significant Fas expression was detected in infiltrating lymphocytes. This would be another reason for protection of islets by FasL positive testicular tissue.

To examine whether the protection of islets by FasL-positive testicular tissue is mediated locally or systemically, we transplanted testicular tissue into the contralateral kidney separate from islet tissue. When $\mathrm{C} 3 \mathrm{H}$ islets and the same amount of $\mathrm{C} 3 \mathrm{H}$ testicular tissue were transplanted separately into the contralateral kidney, the islets were rejected in a normal manner. These data suggest that the protective effect of FasL-positive testicular tissue is locally limited. This is consistent with the finding of Lau et al. [9] who showed that islet allografts transplanted separately from FasL-expressing myoblasts into the contralateral kidney were rejected in a normal manner.

Abrogation of neutrophil recruitment might substantiate the utility of FasL to protect allografts from T-cell-mediated rejection, but the testis and islet composite grafts were eventually rejected in our model. Currently, we cannot explain the difference between our results and those of Bellegrau et al. [12] although these difference might be attributed to a difference in the specific activity of FasL due to polymorphism.

A critical number of FasL-expressing cells is necessary for long-term protection of a composite graft. In our study, islet and testicular tissue composite allograft contained approximately $4 \times 10^{5}$ Sertoli cells. When a smaller population of $\mathrm{C} 3 \mathrm{H}$ testicular tissue $\left(2 \times 10^{5}\right.$ cells $)$ was transplanted together with $\mathrm{C} 3 \mathrm{H}$ islet, no prolongation of graft survival was observed. On the other hand, when a larger amount of testicular 
tissue $\left(2 \times 10^{6}\right.$ cells $)$ was transplanted, the recipient mice failed to achieve normoglycaemia after transplantation, possibly due to a poor nutritional condition around the islets. This finding is consistent with that of Lau et al. [9] who showed that a reduction in the number of FasL expressing myoblasts (from $2 \times 10^{6}$ to $1 \times 10^{4}$, equivalent to $6.6 \times 10^{3} /$ islet and $3.3 \times 10^{1} /$ islet, respectively) co-transplanted with the islet allograft resulted in a decrease in MST and that blood glucose concentrations fluctuated in less than $25 \%$ of the animals receiving a large number of myoblasts within the first 10 days after transplantation. Korbutt et al. [16] also reported a similar finding that testicular cell aggregates (containing $11 \times 10^{6}$ cells, more than $75 \%$ Sertoli cells) together with 2000 purified Lewis rat islets $\left(5.5 \times 10^{3} /\right.$ islet $)$ reversed the diabetic state for more than 95 days in WistarFurth recipients, but testicular tissue samples containing $50 \%$ fewer testicular aggregates did not [16]. Considered together, it seems that an appropriate number of FasL-positive cells per islets $\left(>1 \times 10^{3} /\right.$ islet) is necessary to provide local protection of the islets.

In conclusion, our present study clearly indicates that allograft rejection can be controlled by composite grafting of FasL-positive testicular tissue that induces apoptosis of graft infiltrating mononuclear cells without neutrophil recruitment. Further studies are in progress for successful clinical application of the present findings.

Acknowledgements. This work was partly supported by the Grants from Japanese Ministry of Education, Culture, and Science.

\section{References}

1. Trauth BC, Klas C, Peters AM et al. (1989) Monoclonal antibody-mediated tumor regression by induction of apoptosis. Science 21: 301-305

2. Yonehara S, Ishii A, Yonehara M (1989) A cell-killing monoclonal antibody (anti-Fas) to a cell surface antigen codownregulated with the receptor of tumor necrosis factor. J Exp Med 169: 1747-1756

3. Owen-Schaub LB, Yonehara S, Crump WL III, Grimm EA (1992) DNA fragmentation and cell death is selectively triggered in activated human lymphocytes by Fas antigen engagement. Cell Immunol 140: 197-205

4. Watanabe-Fukunaga R, Brannan CI, Copeland NG, Jenkins NA, Nagata S (1992) Lymphoproliferation disorder in mice explained by defects in Fas antigen that mediates apoptosis. Nature 356: 314-317

5. Lynch DH, Watson ML, Alderson MR et al. (1994) The mouse Fas-ligand gene is mutated in gld mice and is part of a TNF family gene cluster. Immunity 1: 131-136

6. Takahashi T, Tanaka M, Brannan CI et al. (1994) Generalized lymphoproliferative disease in mice, caused by a point mutation in the Fas ligand. Cell 76: 969-976

7. Bellgrau D, Gold D, Selawry H, Moore J, Franzusoff A, Duke RC (1995) A role for CD95 ligand in preventing graft rejection. Nature 377: 630-632
8. Griffith TS, Brunner T, Fletcher SM, Green DR, Ferguson TA (1995) Fas ligand-induced apoptosis as a mechanism of immune privilege. Science 270: 1189-1192

9. Lau HT, Yu M, Fontana A, Stoeckert CJ Jr (1996) Prevention of islet allograft rejection with engineered myoblasts expressing FasL in mice. Science 273: 109-112

10. Allison J, Georgiou MH, Strasser A, Vaux LD (1997) Transgenic expression of CD95 ligand on islet $\beta$ cells induces a granulocytic infiltration but does not confer immune privilege upon islet allografts. Proc Natl Acad Sci USA 94: 3943-3947

11. Kang MS , Schneider BD, Lin Z et al. (1997) Fas ligand expression in islets of Langerhans does not confer immune privilege and instead targets them for rapid destruction. Nature Med 7: 738-743

12. Kayagaki N, Yamaguchi N, Nagao F et al. (1997) Polymorphism of murine Fas ligand that affects the biological activity. Proc Natl Acad Sci USA 94: 3914-3919

13. Tamatani T, Miyasaka M (1990) Identification of monoclonal antibodies reactive with the rat homolog of ICAM1 , and evidence for a differential involvement of ICAM-1 in the adherence of resting versus activated lymphocytes to high endothelial cells. Int Immunol 2: 165-171

14. Gotoh M, Maki T, Kiyoizumi T, Satomi S, Monaco AP (1985) An improved method for isolation of mouse pancreatic islets. Transplantation 40: 437-438

15. Fawcett DW (1986) Male reproductive system. In: Fawcett DW (ed) Bloom and Fawcett a textbook of histology. Saunders, Philadelphia, pp 798-802

16. Korbutt SG, Elliott FJ, Rajotte VR (1997) Cotransplantation of allogeneic islets with allogeneic testicular cell aggregates allows long-term graft survival without systemic immunosuppression. Diabetes 46: 317-322

17. Seino K, Kayagaki N, Okumura Ko, Yagita H (1997) Antitumor effect of locally produced CD95 ligand. Nature Med 3: 165-170

18. Yagita H, Seino K, Kayagaki N, Okumura K (1996) CD95 ligand in graft rejection. Nature 379: 682

19. Baggiolini M, Clark-Lewis I (1992) Interleukin-8, a chemotactic and inflammatory cytokine. FEBS Lett 307: 97-101

20. Cacalano G, Lee J, Kikly K et al. (1994) Neutrophil and B cell expansion in mice that lack the murine IL-8 receptor homolog. Science 265: 682-684

21. Abreu-Martin MT, Virdrich A, Lynch DH, Targan SR (1995) Divergent induction of apoptosis and IL-8 secretion in HT-29 cells in response to TNF-alpha and ligation of Fas antigen. J Immunol 155: 4147-4154

22. Sekine C, Yagita H, Kobata T, Hasumura T, Nishioka K, Okumura K (1996) Fas-mediated stimulation induces IL-8 secretion by rheumatoid arthritis synoviocytes independently of Cpp32-mediated apoptosis. Biochem Biophys Res Commun 228: 14-20

23. Tanaka M, Suda T, Takahashi T, Nagata S (1995) Expression of the functional soluble form of human Fas ligand in activated lymphocytes. EMBO J 14: 1129-1135

24. Mariani S M, Matiba B, Baumler C Krammer P H (1995) Regulation of cell surface APO-1/Fas (CD95) ligand expression by metalloproteases. Eur J Immunol 25: 2303-2307

25. Kayagaki N, Kawasaki A, Ebata Tet al. (1995) Metalloprotease-mediated release of human Fas ligand. J Exp Med 182: $1777-1783$

26. Yamada K, Takane-Gyotoku N, Yuan X et al. (1996) Mouse islet cell lysis mediated by interleukin-1-induced Fas. Diabetologia 39: 1306-1312

27. Chervonsky VA, Wang Y, Wong SF et al. (1997) The role of Fas in autoimmune diabetes. Cell 89: 17-24 